\title{
ABC (DE)'S STAGES OF RELATIONSHIP AS SEEN IN HENRY JAMES'S THE PORTRAIT OF A LADY
}

\author{
Dyah Aju Hermawati \\ ermawati26@yahoo.com \\ English Department State Polytechnic of Jember
}

\begin{abstract}
This article with reference to James's novel The Portrait of a Lady (1881) tries to describe Isabel's stages of relationship. Henry James is primarily known for series of major novels in which he portrayed the encounter of Americans with Europeans, and his plot centered on the personal relationship. Relationship is one of the most domineering and recurring motifs in the works of James. James' main contention for personal relationship is that a relationship develops through stages of relationship. To analyze it, George Levinger's stages of relationship theory is applied, starting from the (A) attraction stage, (B) building stage, (C) continuation stage, (D) deterioration stage and (E) ending stage. Based on the analysis, it can be described that Isabel's relationship with Osmond develop through five stages of relationship. It is began when they are attracted each other and building a relationship, then their relationship become consolidated. When they feel that their relationship as less desirable or worthwhile and the deterioration can not be stopped, they end their relationship due to lack of love, trust and mutual understanding as the root cause for the failure of a relationship. Hence, in a relationship individuals should be aware of loving, understanding, trusting each other and caring commitment to continue and maintain a relationship for long term success.
\end{abstract}

Key Words : personal relationship, stages of relationship

\begin{abstract}
Abstrak
Artikel tentang novel Henry James yang berjudul The Portrait of a Lady (1881) bertujuan mendeskripsikan tahapan-tahapan hubungan dari tokoh utama wanita, yaitu Isabel Archer. Henry James adalah penulis yang terkenal dengan novel-novelnya yang mendeskripsikan hubungan antara orang Amerika dengan orang Eropa, dan alur ceritanya berpusat pada hubungan antar individu. Hubungan antar individu adalah motif yang dominan pada tulisan James, terutama bahwa suatu hubungan antar individu akan berkembang melalui tahapan-tahapan hubungan.Untuk menganalisanya, diaplikasikan teori tahapan-tahapan hubungan George Levinger, mulai dari tahapan perkenalan (Attraction Stage), tahapan membangun suatu hubungan (Building Stage), tahapan melanjutkan hubungan (Continuation Stage), tahapan kemunduran hubungan (Deterioration Stage) dan tahapan akhir hubungan (Ending Stage). Berdasarkan analisa, dideskripsikan bahwa hubungan Isabel dan Osmond, berkembang melalui lima tahapan hubungan. Mulai dari tahapan perkenalan, yaitu tahap mereka pertama kali bertemu, kemudian tahapan membangun suatu hubungan yang lebih dekat, sampai berlanjut pada satu ikatan berkomitmen. Ketika mereka mulai merasakan bahwa hubungannya tidak lagi diinginkan dan mengalami kemunduran, dan hal ini tidak dapat dihentikan, maka mereka mengakhiri hubungan. Sebab utama kegagalan suatu hubungan karena kurangnya kasih sayang, kepercayaan dan pengertian. Oleh karena itu untuk menjalin suatu hubungan, antar individu harus saling mengerti dan percaya satu sama lain dan selalu memegang komitmen serta menjaga hubungan tersebut berlansung sukses.
\end{abstract}

Kata-kata Kunci: hubungan antar individu,Tahapan-tahapan hubungan 


\section{INTRODUCTION}

The Portrait of a Lady is a story of a young American lady, Isabel Archer, who left Albany, America under the auspices of her wealthy aunt, Mrs Touchett (Lydia), to Europe. The first glimpse of Isabel shows that she is "quite independent" (15). This early description sets expectations for her character. Isabel's charisma could be felt by people that were strangers to her. Her attitude and stubborn personality shine through and can be visible in everything she does. A little later at Gardencourt, Isabel is appalled at the very idea of being considered "a candidate for adoption" after her aunt takes her away from her home where she had no parents.

With the passing of time at Gardencourt, Isabel Archer reveals more of her headstrong qualities. Moreover, she accepts a large amount of money from her uncle which changes her life. Isabel's newly acquired fortune brings her an enlarged freedom. Consequently, Isabel believes that she is now freer than ever before. She is free- she thinks- to choose her own fate, included to decide entering a relationship with Gilbert Osmond, and in developing their relationship, they go through each stage of relationship that is started from;

\section{A. Attraction Stage}

The attraction stage of relationship begins at the first sight of someone. It is based on anything that make two person meet each other by chance or design of others, those may be a parent, a family or a friend. The last one is described in Isabel's attraction stage of relationship.

The attraction stage of Isabel's relationship with Osmond begins at Isabel's first sight of Osmond, an Europeanized American, on May at the social gathering of the Palazzo Crescentini, Mrs. Touchett's home in Florence. It is schemed by Madame Merle, an old friend of Osmond who wants to match-making Isabel with Osmond, since she knows that Isabel has inherited a lot of money, in the meantime Osmond is a fortune seeker. It makes Madame Merle thinks that by bringing together those with such interest, the chances of succesful match are greatly enhanched. To realize her plan, Madame Merle, the third person helping out, recommended him to Isabel as "one of the finest gentlemen in all of Europe that is agreeable for being her husband. Madame Merle spoke to Isabel a fresh about Gilbert Osmond and expressed the hope she might know him"( 344). "She also had placed Mr. Osmond near the top of the list and he was one of the cleverest and most agreeable men-well, in Europe simply"(344).

In this type of relationship, more information from the third person as a matchmaker is often needed to motivate a desire to meet. With enough information, the motivation for a relationship begins, like Isabel's motivation to become acquainted with Osmond. After Madame Merle has spoken highly of Osmond, her motivation to know him greater. Isabel is so welcome an 
opportunity to meet Osmond. "Isabel said she should be happy to know a person who had enjoyed so high a confidence for so many years" ( 345$)$.

In attraction stage of relationship, every woman who will meet her new acquaintance at the first time (by design of other) must be nervous and unconfident caused by a responsibility for her to get a positive first impression of the gentleman. To solve them, something general and light may be a good way to start a conversation. Isabel and Osmond's conversation is included a light conversation meant to survey the possibility of a closer personal relationship between them. In addition to a light conversation, the aspect of the appearance, highly manner and attractive personality are usually needed by both of them to get best impression, and then they decide whether a relationship will be continued or not to next phase. It is not similar with two person who meet by chance (without scheme), at the first meeting they will show spontaneous acts (the real image) without considering to get best impression of a person he/she meets.

Sometimes appearance plays an important role in making the first impression as well. It also happened in Isabel's attraction stage of relationship. There is something about Osmond that attracts Isabel. She saw him as the exact image of what she has been seeking after: she is so impressed with Osmond's refined manner, highly cultured, yet lonely and helpless. The first show of Osmond "the more grateful as his face, his head, was sensitive; he was not handsome, but he was fine, as fine as one of the drawings in the long gallery above the bridge of the Uffizi. And his very voice was fine"(349). Isabel's attraction to him remains strong and it is honestly confessed by Isabel.

An attraction in a relationship can never be done by one's side. If it does so, a relationship never goes through the next stage, means that a relationship is ended before it ever begun. It becomes differently if both parties invest their intense mutual attraction, and it can be said that their relatisionship is in the attraction stage, as seen in Isabel's relationship. Isabel's attraction to Osmond is replied by inviting her over to Osmond's beautiful villa, with the hope Isabel can meet his daughter, Pansy and see his extensive art collection.

From their repeated meetings, Isabel and Osmond move through an attraction series of stages that are characterized by increasing involment. They get to know each other more deeply. Isabel learns that Osmond's wife is dead and that his daughter Pansy lives in a convent, and that he has an annoying sister, Countess Gemini and she also notes that Osmond and Madame Merle have a curiously close relationship. On the other side, Osmond also learns that Isabel is a young woman who is fond of her liberty and it is particularly important for him to understand of Isabel's fortune. This can be a basic exchange in their relationship. 
One of the requirements entering a relationship is trying to know the existence of her/his partner, and it can be achieved by having meetings. The meeting of the two person that commonly happened through repeated times could be an indicator that there is a personal relationship as seen in a relationship between Isabel and Gilbert Osmond. Since Isabel has seven times meetings with Osmond, it evidently prove that they begin entering into a relationship, that is in attraction stage of relationship.

\section{B. Building Stage}

The building stage is a crucial phase, because there will be some things for Isabel and Osmond who like one another to seek communality in anything with which to continue conversation. Both of them in this phase build their on initial interest, asking question to learn more about each other and assess compatibility. Through a series of questions and answers, they explore the other's common interests and shares a basic information about their values, beliefs and expectations in hopes that the other person agrees and furthers the social connection. Many relationships end in this stage, never developing acquaintanceship.

The building stage of Isabel's relationship with Osmond is characterized by their potential to be a couple which is getting closer and trying to establish the common ground progress in anything that can build a foundation of relationship. The aspects of building a stable foundation for a relationship are to start trusting each other and to share their ideas in order they do not become a stranger. is expressed by them when they are in the garden of Osmond's terrace at the afternoon and " the scene had an extraordinary The demonstration of trusting to each other charm". (372)

Isabel looks so happy and Osmond could clearly read this situation and thinks that their attraction -Isabel is attracted to Osmond, the man who presents himself to her seemingly without a system, to maintain her freedom, likewise Osmond chiefly interested in Isabel's wealth- will be continued to the building stage of relationship. By keeping a promise to see again, meant Isabel and Osmond are starting to trust each other that becomes a fundamental for a succesful relationship. As Isabel and Osmond get to know and trust one another, more graduallly and slowly they come from being stangers to being lovers.

During this stage, Isabel and Osmond should be encouraging and supporting the idea one another They must understand what their partner want to do and try to do. It is important to do this because it balances their relationship and makes it more equal. Also significant in providing support is encouraging the partner in their strengths, and assisting them in weakness. One of the scenes that indicates Isabel shares her idea with Osmond about her plan to travel around 
the world. Isabel is very shy when she tells Osmond that she has a plan to realize her freedom by going around the world. According to her, her idea is frivolous. But it is different with Osmond's idea. Osmond thinks that Isabel's plan to go around the world is something which is full of pleasures that should be done and it is not necessary for her to be ashamed as Osmond said to her "I don't see why you should be ashamed; it's the greatest of pleasures."(373) This is an evidence that he cares about and concerns for Isabel's desire and always be there for Isabel in her time of greatest need. On Isabel's side, it proves that Isabel is able to share ideas with Osmond. She does not keep what her desire, dream and achievement or anything else to Osmond.

Another aspect of the building stage is when Isabel and Osmond are no longer to be strangers. To develop a relationship to the next level should be an effort of both parties to know and understand more about his/her partner background. Each one tries to find out their partner's origin, family members, educational qualification, interests, hobbies and so on. By reducing the level of uncertainty between them, they come closer to each other. It can be traced when Isabel asks about Osmond's life and Osmond said that “...and I shall have to do what's best for Pansy.'...She is my great happiness" (375-376). Osmond's priority in life is for his daughter, Pansy. It can be inferred that Osmond is able to present a positive impression by changing his adventurer's image to fatherhood's image.

Isabel and Osmond establish a common ground progress to intensifying stage, deepening the relationship. The relationship becomes less formal, and they engage in reciprocal selfdisclosure, revealing more private and personal issues and indicating interest in strengthening the relationship. Behaviours typically expressed during this stage include spending more time together. Isabel spends more time with Osmond in Rome, a wonderful ground and on the beautiful month of May — "the most precious month of all to the true Rome lover. Isabel would become a Rome-lover; --“(400). This moment actually is a chance for Isabel to declare her building relationship with Osmond and to show her completely free to choose to do against what appears most proper and expected of her. But Osmond only wants Isabel to know his interest in having a relationship with her and also perceives it as a realization of his willingness to establish his relationship with Isabel.

The certain point of Isabel's building relationship is when Osmond expresses his feeling of love to Isabel with simplicity of the declaration. Words of love said in privacy, but it does not loose any bit of their meaning and probably even gain some.This makes sense for Osmond, gives declaration of love to Isabel first. "I'm absolutely in love with you."(437) 
Traditionally more emphazing its men who declare their feelings first than its women. with confidence and bravery, Osmond declares his love be sincere which is -a kinf od deeply sincerity or not - only known by Osmond himself. But the first reaction of Isabel to hear Osmond's feeling "The tears came into her eyes"(438). She is really touched with this announcement of Osmond's love. It could be a love. Although there is no a definite answer from Isabel, her face shows that she will continue her relationship to the next stage.

\section{C.Continuation Stage}

After Isabel and Osmond pass the building stage and have determined the relationship is worth pursuing, they enter the continuation stage, in which they put forth the effort to enhance the positive factors of the relationship. An example of them would be demonstration of affection, building trust, and caring commitment, and their lives becomes enmeshed.

The expression of affection is very important in a relationship. It is anything that could be done or said to or about the partner. If it can not be shown by the physical aspect, it needs to be shown in words, as what Osmond does. Since there is no evidence in the text that suggests Osmond arouse physical affection, Osmond demonstrates his affection by telling to lsabel how much he is lucky to meet and love her. "It has made me better, loving you", he said on another occasion; it has made me wiser and easier and I won't pretend to deny- brigther and nicer and even stronger.(496) Osmond makes more an effort to be verballly expressive of his feelings in order to make Isabel would be affectionate, feel better about herself, and becomes more attracted to him, and those cause Isabel feel encouraged, loved and validated. In traditionally relationship men did firstly. Thus it is not surprising if Osmond himself tries to give his affection as a form of his attempt to maintaining his relationship with Isabel for long term success. On the contrary, Isabel, in order to be the perfect Victorian lady, she is discouraged from exploring her verbal and non-verbal affection. Thus, she feels obligated to control them as it was nor proper for a lady to express such emotions, that is called affection.

Another aspect of continuation stage of relationship is that caring commitments. Commitment is the base of relationship that makes a relationship stronger and healthier. In a relationship, a commitment could be made between two persons, or it could be a commitment between each person with herself/himself. True commitment comes after building stage of relationship. The first commitment of Isabel and Osmond's relationship is arouse when "their engagement had been made public"(479). Engagement issue is not single minded decision. It should be a commitment between Isabel and Osmond, It can be traced that Isabel and Osmond's relationship becomes more consolidated. They believe that they want to share Stogether, and 
the love that they belong to is something to be deservedly achieved. That is a major commitment decision of Isabel and Osmond relationship then realized by getting married. When it came time for Isabel to marry, there had been a very quiet service - the couple's wedding takes place off stage and in a small ceremony- with only her aunt and cousin invited. The Countess Gemini and Pansy Osmond were the only other people present.

Another form of their commitment related to their decision of deciding to where they settle after they got married. As Isabel inherited fortune, she can live anywhere in Europe. On another side, Osmond lives in Florence, thus "they made a good many plans, but they left themselves also a good deal of latitude; it was a matter of course, however, that they should live for the present in Italy. It was in Italy that they had met, Italy had been a party to their first impressions of each other, and Italy should be a party to their happiness." (497). Isabel and Osmond decide to stay in Italy, since that is where their relationship blossomed. Italy, "to the Palazzo Roccanera, on settling themselves in Rome she and her husband had chosen this habitation for the love of local colour"( 515)

By Isabel's marrying to Osmond shows that sabel's relationship is on the continuation stage of relationship. Related to Levinger's theory of relationship, during this stage, if both parties remain committed to the continuation and relationship maintenance necessary for long term success, their relationship will lead to lasting commitment until fate separates them. But if Isabel and Osmond do not involve in their full expression to the reciprocal response of the total being of one another, or if they do not commit to each other in order to share their value, hope, and desire, then the last two stages of their relationship: deterioration and ending are not completely avoidable.

\section{D.Deterioration Stage}

This is not a good stage, and it must be avoidable. There are some basic reasons that can be identified for the failure of marriage. The first and foremost reason is a very common and universal one-lack of mutual understanding and trust. Mutual understanding and trust lead to adjustment and without adjustment, any relationship will stifle. It could be seen in Isabel's relationship with Osmond.

The reason that deteriorates Isabel's relationship with Osmond is about the different motivations and objectives in approaching marriage, money, status and social obligation, when any of these motivations and objectives get foiled, its result in the failure of the relationship. It is described in Isabel and Osmond's relationship. Whereas before the only liberty Isabel could envision was her desire to travel the world, she now feels that marriage to Osmond would be 
one way she could exert her independence, by marrying the man of her choice, it is allowing her to be freer. Firstly, Isabel's motivation to marry Osmond, the man she chooses by herself, is that to realize her completely freedom and Isabel was deluded to think of Osmond as the man with higly manner will allow her the most freedom which she adores the most in her life. She failed to realize before their marriage, that Osmond was actually using them to achieve his selfish ends. Isabel becomes a victim of her ideals when she tries to choose the best husband for herself without completely knowing the true Gilbert Osmond. After the marriage, she discovers that Osmond is exactly opposite of what she thought him to be. The fact about him is fortune hunter. Osmond marries her only for her monetary resources, inherited from her deceased uncle Touchett. As in the words of Osmond, "money's a horrid thing to follow and a charming thing to meet"(496). By money Osmond thinks that he has high position in the society. Osmond's desire consists of living life in the highest social form and having those individuals around him also living up to his finished social standing. It motivates him to marry Isabel. Who not only has money, but whom he considers capable of devotion. Meanwhile, Isabel marries Osmond not for money, he is penniless. Isabel thinks that she finds Osmond, the ideal lover for her. Her reason for marrying Osmond is given in her own words as "I think I owe him that. I think I owe it to myself" (594) ). Isabel marries is a form of her social obligation. However, she does not completely engage in the social expectation of her. As a upper-class woman, Isabel is encouraged to marry a wealthy man who could provide for her and allow her to lead lives of leisure. But Isabel wants to believe that she can choose her fate, but she cannot. Isabel comes to view men only in passive terms and sees them only as abstractions. This situation can urge the deterioration of one's relationship, as what Isabel experiences

Isabel may feel that there are too many things happening in their relationship that make her unhappy or uncompartable, she feels that circumstances make the relationship too difficult whatever the reason. One of the most powerful scenes in this novel is to have insight into Isabel's private, intimate thoughts as she sits in her room and reflects on how her marriage to Osmond is failing. She admits to herself that she conceived, "It was her deep distrust of her husband - this was what darkened the world."(600)

Soon in their marriage, Isabel believes that her husband hates her. He told her that she had too many ideas and that she needed to get rid of them (602). Osmond hates her because she has a mind of her own whereas he would prefer his wife be completely submissive to him. Isabel realizes that her relationship is less desirable, and her marriage fails miserably and is irreparable. She ruminates that she did not show her entire self to Osmond during the one year they courted. Isabel reflects that" she had effaced herself when he first knew her: she made 
herself small, pretending there was less of her than there really was" (602) perhaps means that she had not shown Osmond what a truly independent thinker she was, that she had her own opinions and stood by them, infuriated Osmond. She recognizes that as the marriage proggessed, she came to see her husband's true character "She saw the full moon now-she saw the whole man" (602). Since Osmond does not change, the change seems to be in Isabel. She becomes aware of her ideals and of Osmond's ideals and she realizes how different they are. In a relationship, no one has shown the other his or her entire personality, like Isabel and Osmond's relationship, and when they reveal their entire selves to each other, Isabel and Osmond find they do not love each other in their entirety.

The marital life of Isabel with Osmond begins to be bitter for her due to Osmond's lack of genuine affection for his wife, Isabel. "They were strangely married, at all events, and it was a horrible life “(612 ), for "he can't love any one.'(644). The tragedy of her marriage comes to her when she discovers that Osmond and Madame Merle had once been lovers and that she has been deceived by both of them into a bad marriage. Isabel's confusion is cleared up when the Countess Gemini tells her the truth about Madame merle, Osmond and Pansy's relationship. Isabel is shocked by what she is told even though she has noticed the familiarity between Osmond and Madame Merle. She realizes that Osmond has not change, he is still controlled by his memory of his former lover, Madame Merle. Osmond's inability to remove his memory with Madame Merle makes lack of his affection for his wife, Isabel.

It is not easy situation for Isabel and she experiences difficult times when secrets come up in marriage and it causes a conflict in their relationship. She may be having difficulty accepting her husband for who he is and disappointed to her husband's intentions are not what they first seem.

Isabel's relationship with Osmond may deteriorate due to imbalance of costs and rewards. Both of them have an expectation from their partner, if Isabel's expectation from Osmond is that he still maintain her freedom, likewise Osmond-besides money as the main reason in marrying Isabel- wants an expectation that Isabel will submissive to him. Therefore, it is so difficult for them to adjust with each other and eventually this situation brings their relationship to the ending stage of relationship.

\section{E. Ending Stage}

The last stage of relationship is the ending stage. It is when both parties are not able to stop the deterioration in their relationship, as what happened in Isabel's relationship with Osmond.

The ending stage of Isabel's relationship with Osmond is characterized when Isabel knows the truth about her husband, Osmond, Madame Merle, and Pansy's relationship. Being shocked 
and sadness, as described 'Isabel's brow had contracted to a frown; her lips were parted in pale“(766), and she makes a decision to leave her husband. She chooses to go to meet the dying cousin, Ralph Touchett although it is against her husband's wish. "Ah, I must see Ralph!”...” And will papa go ?’ No; I shall go alone" (784)

It indicates that her relationship with her husband, Osmond is not worthwhile. In general, a woman should ask a permission from her husband to go out or visit her relatives. On the other side, a husband, with mutual understanding and trust, will give a permission to his wife and accompany her, but it does not happen in Isabel and Osmond's relationship. Since Osmond wants to deny her any freedom of thought, meanwhile he knows that Ralph encourages her freedom, they become the reasons why Osmond never allow Isabel to visit Ralph. Without her husband, Isabel still leaves for Gardencourt to see Ralph. It might be the failure of their relationship. It can be traced that asking husband's permission may not be necessary but it would hurt the marriage, it would be grounds for separation of both parties.

Most of people will have to face the problem in their relationship. and both parties are not able to solve it, even not rarely that one partner will leave her or his partner. Sometimes it is regarded as a good chance, because it can give a fresh time for each couple to think about her or his relationship deeply. It will help each partner to make a decision on their relationship. it will be ended or brought to the second chance of the relationship, as seen in Isabel and Osmond's relationship.

Isabel is so desperately unhappy in her marriage to Osmond, she is faced with one final choice. She must decide whether she will remain in this unhealthy marriage with Osmond and try to protect her stepdaughter Pansy or run off with her old suitor Caspar Goodwood. However, it does not explicity write such as an ending. It allows that it is up to the reader to decide what Isabel would have done.

\section{CONCLUSION}

Related to Levinger's theory of relationship, during this stage, if both parties remain committed to the continuation and relationship maintenance necessary for long term success, their relationship will lead to lasting commitment until fate separates them. Isabel deteriorates Isabel's relationship with Osmond is about the different motivations and objectives in approaching marriage, money, status and social obligation, when any of these motivations and objectives get foiled, its result in the failure of the relationship. It is described in Isabel and Osmond's relationship. The last stage of relationship is the ending stage. It is when both parties are not able to stop the deterioration in their relationship, as what happened in Isabel's 
relationship with Osmond. The ending stage of Isabel's relationship with Osmond is characterized when Isabel knows the truth about her husband, Osmond, Madame Merle, and Pansy's relationship. Therefore, Hence, in a relationship individual should be aware of loving, understanding, trusting each other and caring commitment to continue and maintain a relationship for long term success.

\section{REFERENCES}

James, Henry. 1881. The Portrait of a Lady published by Planet eBook, licensed under a Creative Commons Attribution-Noncommercial 3.0 United States License in 2008.(http://www.planetebook.com/The-Portrait-of-a-Lady.asp)

Nevid, J. S., \& Rathus, S. A. 2005. Psychology and the challenges of life: Adjustment in the new millennium ( $9^{\text {th }}$ ed.). Hoboken, NJ: John Wiley \& Sons.

Powers, Lyall H., 1970, Henry James: An Introduction and Interpretation, New York: Holt, Rinehart, Winston, Inc. 